\author{
Jurnal Ekonomi Modernisasi \\ http://ejournal.unikama.ac.id/index.php/JEKO \\ JEM 13 (2) 2017, 94-104
}

\title{
Peran Identifikasi Merek dan Citra Merek dalam Mempengaruhi Cinta kepada Merek
}

\author{
Ferdian Hendrasto \\ Fakultas Ekonomi dan Bisnis, Universitas Gajayana
}

\begin{abstract}
This research aims to synthesize two major antacedents of brand love, which are brand identification and brand image. Research is conducted using multiple regression analysis, whereas data collection is conducted using online questionnaire. The sample of this research is community members of a prominent video games franchise, The Elder Scrolls series. The empirical result shows that both variables not only influence brand love partially, but also simultaneously. Thus, practitioners who aim to improve the consumer-brand relationship should develop their marketing strategy around a strong brand image and a solid brand identification.
\end{abstract}

Keywords: Brand love; Brand Identification; Brand Image

Abstrak

Penelitian ini bertujuan memadukan dua faktor yang mempengaruhi cinta kepada merek, yaitu identifikasi merek dan citra merek. Penelitian dilakukan dengan menggunakan analisis regresi berganda, dan pengumpulan data dilakukan menggunakan bantuan kuesioner secara daring. Sampel penelitian ini adalah anggota komunitas dari franchise video game, The Elder Scrolls. Hasil penelitian empiris menunjukkan bahwa kedua variabel, identifikasi merek dan citra merek, tidak hanya mempengaruhi cinta kepada merek secara parsial, namun juga secara simultan. Oleh karena itu, peneliti yang hendak meningkatkan hubungan antar konsumen dengan merek dapat mendesain strategi pemasaran dengan membangun citra merek yang kuat dan identifikasi merek yang solid.

Kata kunci: Cinta kepada Merek; Identifikasi Merek; Citra Merek.

\begin{tabular}{ll}
\hline Permalink/DOI $\quad:$ http://dx.doi.org/10.21067/jem.v13i2.1761 \\
Cara mengutip $\quad:$ Hendrasto, F. (2017). Peran Identifikasi Merek dan Citra Merek dalam Mempengaruhi \\
& $\begin{array}{l}\text { Cinta kepada Merek.Jurnal Ekonomi Modernisasi, 13(2), 94-104 doi:http:// } \\
\text { dx.doi.org/10.21067/jem.v13i2.1761 }\end{array}$ \\
Sejarah Artikel $\quad:$ Artikel diterima : Mei 2017; direvisi Juni 2017; disetujui Juli 2017
\end{tabular}

Alamat korespondensi :

Fakultas Ekonomi dan Bisnis, Universitas Gajayana

ISSN 0216-373X (cetak)

Jl. Mertojoyo, Merjosari, Malang, , Indonesia, 65144

ISSN 2502-4578 (online)

E-mail: ferdianhendrasto@gmail.com 


\section{Pendahuluan}

Beberapa tahun belakangan ini, peneliti dalam bidang pemasaran telah banyak meneliti tentang sikap konsumen terhadap merek, khususnya komponen afektif konsumen dalam menilai sebuah merek, yaitu tingkat kesukaan atau ketidaksukaan konsumen dalam menilai sebuah merek. Salah satu komponen afektif yang sering diamati oleh peneliti dalam beberapa tahun belakangan ini adalah rasa cinta kepada merek (brand love). Beberapa peneliti fokus pada konsep cinta terhadap merek, yaitu Roberts (2005) yang menulis buku berjudul "Lovemarks: The Future Beyond Brands", yang berargumen bahwa strategi branding tradisional tidak relevan lagi dalam dunia modern, yang dibutuhkan adalah love affairs dengan pelanggan, Di lain sisi, ternyata memang ada peningkatan penggunaan kata "cinta" dalam iklan (Bauer, Albrecht, \& Heinrich, 2009)

Penelitian bidang cinta kepada merek diawali oleh penelitian yang dilakukan oleh Shimp dan Madden (1988) yang meneliti tentang hubungan antara konsumen dengan obyek, mereka mengadopsi teori cinta triangular dalam konteks inter-personal yang dikembangkan oleh Sternberg pada tahun 1986. Penelitian empiris di bidang cinta terhadap merek pertama kali dilakukan oleh Ahuvia dan Wong (1995). Beberapa tahun berikutnya, banyak peneliti di bidang pemasaran yang meneliti tentang rasa cinta kepada merek, Fournier (1998) memasukkan rasa cinta sebagai elemen kunci dalam hubungan antara konsumen dengan merek. Carroll dan Ahuvia (2006) meneliti tentang beberapa antaseden dari brand love, Spinelli dan Ismail (2012) meneliti tentang bagaimana rasa cinta kepada merek dapat membangun WOM, Rauschnabel dan Ahuvia (2014) meneliti tentang antropomorfisme dan brand love, Bergkvist dan Bech-Larsen (2010) meneliti tentang rasa cinta kepada merek dalam sebuah komunitas merek.

Walaupun telah banyak peneliti yang meneliti tentang rasa cinta kepada merek, namun antaseden brand love masih diteliti secara sporadis, sehingga sulit bagi praktisi untuk menyusun strategi yang tepat dalam membangun brand love dalam diri pelanggan (Batra, Ahuvia, \& Bagozzi, 2012). Dua antaseden utama dari rasa cinta kepada merek adalah identifikasi merek (Bergkvist \& Bech-Larsen, 2010) dan citra merek (Spinelli \& Ismail, 2012). Oleh karena itu, penelitian ini dilakukan dengan tujuan mensintesis dua antaseden rasa cinta kepada merek, yaitu citra merek dan identifikasi merek untuk mengetahui pengaruh kedua variabel tersebut kepada rasa cinta kepada merek (brand love). Luaran yang diharapkan adalah praktisi dapat mendesain strategi yang tepat dalam membangun love affairs dengan pelanggan.

\section{Tinjauan Pustaka}

\section{Identifikasi Merek}

Identifikasi merek merupakan konsep bahwa konsumen menganggap citra dirinya sesuai dengan citra merek (Bagozzi \& Dholakia, 2006). Selain itu, beberapa peneliti lain mengidentifikasi merek sebagai kongruensi citra (Sirgy et al., 1997) dan koneksi diri (Fournier, 1998). Berdasarkan beberapa definisi identifikasi merek tersebut, dapat disimpulkan bahwa identifikasi merek adalah suatu keadaan ketika persepsi konsumen atas citra merek selaras dengan 


\section{Ferdian Hendrasto / Peran Identifikasi Merek dan Citra Merek .....}

citra dirinya, dengan adanya keselarasan citra merek dengan citra diri, akan memicu komponen afektif konsumen dan timbul koneksi antara diri konsumen dengan merek tersebut.

\section{Citra Merek}

Membangun citra merek adalah salah satu strategi yang paling penting dalam membangun merek yang kuat, sehingga merek tersebut dapat membedakan dirinya dari merek-merek lain yang sejenis (Aaker, 1996). Citra merek didefinisikan sebagai sebuah konsep atas sebuah merek yang dipahami oleh konsumen, citra merek adalah konsep yang subyektif dan tergantung dari persepsi konsumen dalam menginterpretasi sebuah merek baik melalui pemikiran terstruktur maupun emosional (Dobni \& Zinkhan, 1990). Definisi lain citra merek adalah persepsi konsumen atas sebuah merek tergantung dari asosiasi merek tersebut (Kevin L Keller, 1993). Citra merek juga dapat didefinisikan sebagai suatu konsep yang dipikirkan dan dirasakan oleh konsumen tentang merek tertentu (Roy \& Banerjee, 2008). Berdasarkan beberapa definisi citra merek, dapat diambil kesimpulan bahwa citra merek adalah bagaimana seorang konsumen mengevaluasi dan menilai sebuah merek melalui proses pemikiran kognitif dan afektif sehingga terbentuk sebuah persepsi atas konsep merek yang dimaksud.

\section{Cinta Kepada Merek (Brand Love)}

Dalam bidang ilmu psikologi, cinta adalah sebuah konsep bi-direksional yang membutuhkan dua pihak saling menyukai satu sama lain, dalam konsep cinta bidireksional, kedua belah pihak memiliki hubungan intim yang sering kali berujung pada aktivitas seksual (Grunebarum, 1997). Berbeda dengan konsep 'dasar cinta, brand love tidak bersifat bi-direksional, namun unidireksional. Konsumen yang mencintai sebuah merek tentu saja tidak mengharapkan adanya hubungan intim dengan merek yang dimaksud, namun ia tetap memiliki rasa cinta kepada merek tersebut (Whang, Allen, Sahoury, \& Zhang, 2004). Salah satu definisi brand love dikemukakan oleh Carroll \& Ahuvia (2006), rasa cinta kepada merek didefinisikan sebagai: "the degree of passionate emotional attachment a satisfied consumer has for a particular trade name". Berdasarkan beberapa konsep rasa cinta kepada merek, dapat disimpulkan bahwa brand love adalah sebuah hasrat dan perasaan emosional yang timbul akibat kepuasan dalam diri konsumen terhadap merek tertentu.

\section{Identifikasi Merek}

Identifikasi merek timbul karena persepsi konsumen atas keselarasan citra merek dengan citra dirinya sendiri. Penelitian yang dilakukan oleh Kressmann et al. (2006) membuktikan bahwa terdapat hubungan positif antara identifikasi merek dengan hubungan merek (brand relationship). Beberapa dimensi hubungan merek adalah rasa cinta dan rasa gairah (Fournier, 1998). Ketika konsumen memiliki persepsi bahwa sebuah merek adalah ekstensi dirinya, maka akan timbul rasa suka dalam diri konsumen tersebut, sehingga konsumen lebih mencintai merek tersebut (Bergkvist \& BechLarsen, 2010). Berdasarkan latar belakang teori, maka hipotesis penelitian adalah : H1 : Diduga identifikasi merek memiliki pengaruh terhadap cinta kepada merek. 


\section{Jurnal Ekonomi Modernisasi, 13 (2) 2017, 94-104}

\section{Citra Merk}

Citra merek adalah evaluasi seorang konsumen atas sebuah merek melalui proses pemikiran kognitif dan afektif, sehingga timbul sebuah persepsi dalam pikiran konsumen tersebut atas suatu merek. Salah satu komponen citra merek adalah asosiasi merek (Koubaa, 2008), sehingga konsumen akan mengasosiasikan satu merek sesuai dengan informasi yang diterima oleh konsumen, sehingga merek tersebut dapat dikategorikan di dalam ingatan konsumen (Kevin Lane Keller, Heckler, \& Houston, 1998). Ketika sebuah merek masuk dalam kategori merek yang baik dalam benak konsumen, maka akan timbul perasaan afektif dalam diri konsumen terhadap merek tersebut (Spinelli \& Ismail, 2012). Berdasarkan latar belakang teori, maka hipotesis penelitian adalah :

$\mathrm{H} 2$ : Diduga citra merek memiliki pengaruh terhadap cinta kepada merek.

Penelitian yang dilakukan oleh Langner, Bruns, Fischer, \& Rossiter (2016) meneliti tentang identifikasi merek dan citra merek dalam konteks komunitas pengendara motor, penelitian mereka menyebutkan bahwa kedua variabel ini berperan penting dalam memperkuat hubungan antara konsumen dengan merek tertentu (brand relationship), rasa cinta merupakan salah satu faktor utama dari timbulnya hubungan antar konsumen dan merek (Fournier, 1998). Ketika konsumen menganggap bahwa sebuah merek dapat mewakili diri mereka dan mengasosiasikan merek tersebut dengan dirinya, akan memicu hubungan emosional yang mendalam antara konsumen dengan merek. Berdasarkan latar belakang teori, maka hipotesis penelitian adalah :
H3 : Diduga identifikasi merek dan citra merek secara simultan berpengaruh terhadap cinta kepada merek.

Berdasarkan ketiga hipotesis di atas, maka dikembangkan model penelitian yang dapat dilihat pada gambar 1 :

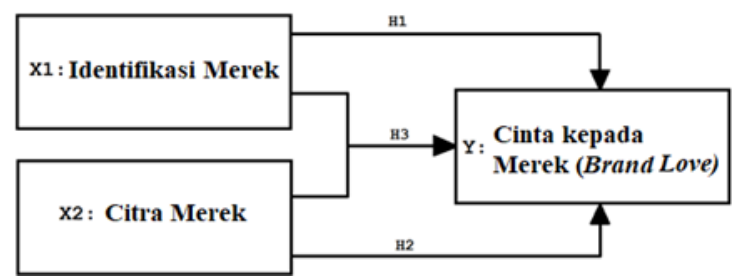

Gambar 1. Model Penelitian

\section{Metode}

Penelitian ini merupakan penelitian kuantitatif yang terdiri atas tiga variabel. Dua variabel bebas yaitu Identifikasi Merek (X1) dan Citra Merek (X2) serta satu variabel terikat yaitu Cinta kepada Merek (Y). Variabel Identifikasi Merek (X1), peneliti menggunakan 5 indikator yang digunakan oleh So et al. (2013), yaitu:

1. Ketika seseorang mengkritik merek ini, saya ikut merasa tersinggung.

2. Saya sangat tertarik dengan apa yang dipikirkan orang lain mengenai merek ini

3. Ketika saya membicarakan merek ini, saya mengucapkan kata kami, bukan $\mathrm{dia} /$ mereka.

4. Kesuksesan merek ini adalah kesuksesan saya.

5. Ketika seseorang memuji merek ini, saya merasa ikut dipuji pula.

Variabel Citra Merek (X2), peneliti menggunakan 5 indikator yang digunakan dalam penelitian Severi dan Ling (2013), yaitu: 


\section{Ferdian Hendrasto / Peran Identifikasi Merek dan Citra Merek ....}

1. Merek ini berbeda dengan merek lain yang sejenis.

2. Saya mempercayai perusahaan yang memiliki merek ini.

3. Merek ini familiar dalam benak saya.

4. Saya memiliki banyak alasan untuk memilih merek ini dibandingkan merek lain yang sejenis.

5. Merek ini memiliki karakteristik tersendiri.

Adapun untuk variabel Cinta kepada Merek (Y), peneliti mengadopsi 5 indikator yang dikembangkan oleh Spinelli dan Ismail (2012), yaitu:

1. Merek ini sangat keren.

2. Merek ini membuat saya bahagia.

3. Saya mencintai merek ini.

4. Saya memiliki ikatan erat dengan merek ini.

5. Merek ini sangat mengasyikkan.

Pengambilan data menggunakan kuesioner daring dengan menggunakan bantuan GoogleForms. Pernyataan dalam kuesioner dinilai dengan menggunakan skala likert dengan 5 pilihan jawaban, di mana skor 1 adalah Sangat Tidak Setuju dan skor 5 adalah Sangat Setuju. Populasi penelitian ini adalah anggota komunitas franchise video games Elder Scrolls pada alamat https:// bethesda.net/community/ dan http:// forums.bethsoft.com/forum/13-the-elderscrolls/. Jumlah minimal sampel yang digunakan adalah 100 responden (Hair dan Black, 2010). Teknik pengambilan sampel menggunakan metode acak sederhana. Teknik analisis menggunakan analisis regresi berganda.

\section{Hasil dan Pembahasan}

Penyebaran kuesioner pada penelitian ini dilakukan kepada 215 orang responden, sebanyak 107 responden mengisi kuesioner dengan sempurna. Response rate sebesar sebesar 50,23\%. Sebanyak 97 responden atau $90,65 \%$ berjenis kelamin pria, sedangkan sisanya sebanyak $9,35 \%$ atau 10 responden berjenis kelamin wanita. Hal ini menunjukkan bahwa dalam industri video games, pria masih merupakan target pasar yang lebih menjanjikan dibandingkan dengan wanita.

Uji instrumen terbagi menjadi dua, yaitu uji reliabilitas dan validitas. Uji validitas dilakukan untuk menganalisis apakah variabel yang diukur benar-benar variabel yang hendak diteliti. Sedangkan uji reliabilitas dilakukan untuk menganalisis apakah instrumen yang diaplikasikan dalam kuesioner dapat dipercaya untuk mengukur informasi di lapangan (Hair, Black, Babin, \& Anderson, 2010).

Hasil uji validitas dan reliabilitas variabel Identifikasi Merek (X1) adalah Tabel 1. Uji Validitas dan Reliabilitas X1

\begin{tabular}{cccc}
\hline Indikator & r-hitung & r-tabel & CR \\
\hline 1. & 0,328 & 0,197 & \\
\cline { 1 - 3 }. & 0,380 & 0,197 & \\
\cline { 1 - 3 }. & 0,494 & 0,197 & 0,828 \\
\cline { 1 - 3 }. & 0,574 & 0,197 & \\
\cline { 1 - 3 } 5 & 0,528 & 0,197 & \\
\hline
\end{tabular}

Sumber: Data diolah 2017

sebagai berikut:

Hasil uji validitas variabel Identifikasi Merek (X1) menunjukkan bahwa semua nilai r-hitung $>$ r-tabel, sehingga semua pernyataan adalah valid. Uji reliabilitas menunjukkan bahwa nilai Cronbach's Alpha sebesar 0,828 >0,70, sehingga dapat diambil kesimpulan bahwa konstruk pernyataan variabel Identifikasi Merek (X1) adalah reliabel. 


\section{Jurnal Ekonomi Modernisasi, 13 (2) 2017, 94-104}

Tabel 2. Uji Validitas dan Reliabilitas X2

\begin{tabular}{cccc}
\hline Indikator & r-hitung & r-tabel & CR \\
\hline 1. & 0,456 & 0,197 & \\
\cline { 1 - 3 }. & 0,554 & 0,197 & \\
\cline { 1 - 3 }. & 0,634 & 0,197 & \\
\hline 4. & 0,418 & 0,197 & \\
\cline { 1 - 3 }. & 0,399 & 0,197 & \\
\hline
\end{tabular}

Sumber : Data diolah 2017

Hasil uji validitas dan reliabilitas variabel Citra Merek (X2) adalah sebagai berikut:

Hasil uji validitas variabel Citra Merek (X2) menunjukkan bahwa semua nilai r-hitung $>$ r-tabel, sehingga semua pernyataan adalah valid. Sedangkan uji reliabilitas menunjukkan bahwa nilai Cronbach's Alpha sebesar 0,759>0,70, sehingga dapat diambil kesimpulan bahwa konstruk pernyataan variabel Citra Merek (X2) adalah reliabel.

Tabel 2. Uji Validitas dan Reliabilitas X3

\begin{tabular}{cccc}
\hline Indikator & r-hitung & r-tabel & CR \\
\cline { 1 - 3 } 1. & 0,656 & 0,197 & \\
\cline { 1 - 2 } 2. & 0,878 & 0,197 & \\
\cline { 1 - 3 }. & 0,877 & 0,197 & \\
\cline { 1 - 2 }. & 0,801 & 0,197 & \\
\hline 5. & 0,634 & 0,197 &
\end{tabular}

Sumber : Data diolah 2017

Hasil uji validitas dan reliabilitas variabel Cinta kepada Merek (X3) adalah sebagai berikut:

Hasil uji validitas variabel Cinta kepada Merek (Y) menunjukkan bahwa semua nilai r-hitung $>$ r-tabel, sehingga semua pernyataan adalah valid. Sedangkan uji reliabilitas menunjukkan bahwa nilai Cronbach's Alpha sebesar 0,869>0,70, sehingga dapat diambil kesimpulan bahwa konstruk pernyataan variabel Cinta kepada Merek (Y) adalah reliabel.

\section{Uji Asumsi Klasik}

Uji asumsi klasik dalam penelitian ini terdiri atas uji normalitas dan uji multikolinearitas. Uji normalitas dilaksanakan untuk mengetahui distribusi data dalam hasil kuesioner yang telah disebarkan normal atau tidak. Peneliti melakukan uji normalitas dengan menggunakan metode KolmogorovSmirnov, nilai signifikansi setelah dilakukan uji normalitas adalah sebesar 0,962 lebih besar dari nilai signifikansi 0,05. Oleh karena itu dapat disimpulkan bahwa data yang diuji dalam penelitian ini terdistribusi normal.

Uji multikolinearitas dilakukan untuk melihat apakah ada hubungan di antara variabel independen penelitian. Pada analisis regresi berganda, adanya multikolinearitas menunjukkan bahwa data tersebut tidak layak untuk dianalisis lebih

Tabel 4. Uji Multikolinieritas

\begin{tabular}{lcc}
\hline \multirow{2}{*}{ Model } & \multicolumn{2}{c}{ Collinearity Statistics } \\
\cline { 2 - 3 } & Tolerance & VIF \\
\hline 1 (Constant) & & \\
\hline Identifikasi Merek & 0,518 & 1,744 \\
\hline Citra Merek & 0,518 & 1,744 \\
\hline
\end{tabular}

Sumber: Data diolah 2017

lanjut. Hasil uji multikolinearitas antar variabel independen penelitian ini dapat dilihat pada tabel di bawah ini:

Berdasarkan tabel 4, nilai tolerance kedua variabel yaitu variabel Identifikasi Merek dan Citra Merek berada di atas 0,1 dan nilai VIF kedua variabel berada di antara 1 dan 10. Oleh karena itu dapat disimpulkan bahwa tidak terjadi multikolinearitas di antara variabel independen Identifikasi Merek dan Citra Merek. 


\section{Ferdian Hendrasto / Peran Identifikasi Merek dan Citra Merek .....}

\section{Uji Hipotesis}

Ketiga hipotesis dianalisis dengan menggunakan metode regresi linier

Tabel 5. Uji Hipotesis

\begin{tabular}{llcc}
\hline \multicolumn{2}{c}{ Model } & $\mathrm{t}$ & Sig. \\
\hline 1 & (Constant) & $-2,559$ & 0,011 \\
& Identifikasi Merek & 7,438 & 0,000 \\
\hline 1 & (Constant) & 0,983 & 0,250 \\
& Citra Merek & 6,314 & 0,000 \\
\hline \multicolumn{2}{c}{ Model } & $\mathrm{F}$ & Sig. \\
\hline $1 \quad$ Regression & & 46,273 & 0,000 \\
\hline R Square (X1) & $: 0,573$ & & \\
R Square (X2) & $: 0,305$ & &
\end{tabular}

Adjusted R Square : 0,549

Sumber : Data diolah 2017

berganda, dibantu menggunakan aplikasi SPSS 21 untuk Windows. Tabel 5 di bawah ini berisi ringkasan hasil uji hipotesis:

Berdasarkan tabel 5 dapat diketahui bahwa Identifikasi Merek memiliki p-value di bawah 0,05 yang artinya signifikan. Nilai t-hitung sebesar 7,438 yang lebih besar dari nilai t-tabel 1,984 yang berarti signifikan. Oleh karena itu, hipotesis pertama yang menyatakan bahwa diduga identifikasi merek memiliki pengaruh terhadap cinta kepada merek adalah diterima. Besaran pengaruh Identifikasi Merek terhadap Cinta kepada Merek dapat dilihat dari nilai $\mathrm{R}$ square sebesar 0,573. Hal ini berarti bahwa 57,3\% variabel Citra Merek dijelaskan oleh variabel Identifikasi Merek sedangkan sisanya sebanyak $42,7 \%$ ternyata dijelaskan oleh variabel lain di luar penelitian ini.

Hipotesis kedua menyatakan bahwa diduga citra merek memiliki pengaruh terhadap cinta kepada merek. Berdasarkan tabel 5 dapat diketahui bahwa Identifikasi Merek memiliki p-value di bawah 0,05 yang artinya signifikan. Nilai t-hitung sebesar 6,314 yang lebih besar dari nilai ttabel 1,984, yang berarti signifikan. Hal ini berarti hipotesis kedua diterima, yang berarti bahwa terdapat pengaruh Citra Merek terhadap Cinta kepada Merek. Besaran pengaruh Identifikasi Merek terhadap Cinta kepada Merek dapat dilihat dari nilai $\mathrm{R}$ square sebesar 0,305 . Hal ini berarti bahwa 30,5\% variabel Citra Merek dijelaskan oleh variabel Identifikasi Merek sedangkan sisanya sebanyak 69,5\% dijelaskan oleh variabel lain yang dalam penelitian ini, tidak ikut diteliti.

Hipotesis ketiga menyatakan bahwa diduga identifikasi merek dan citra merek secara bersama-sama berpengaruh terhadap cinta kepada merek. Dari tabel di atas, diketahui bahwa nilai $\mathrm{p}$-value model regresi berganda di bawah 0,05, yang artinya signifikan. Nilai F-hitung menunjukkan 46,273 berada jauh di atas nilai F-tabel yaitu 2,70, artinya adalah signifikan. Signifikan berarti terdapat pengaruh antara Identifikasi Merek dan Citra Merek secara simultan terhadap Cinta kepada Merek. Maka hipotesis ketiga diterima. Sedangkan besaran pengaruh Identifikasi Merek dan Citra Merek terhadap Cinta kepada Merek dapat dilihat melalui nilai Adjusted R Square sebesar 0,549. Artinya adalah bahwa 54,9\% variabel Cinta kepada Merek dijelaskan oleh variabel Identifikasi Merek dan Citra Merek secara simultan. Sedangkan sisanya yaitu 45,1\% diterangkan oleh variabel lain, selain dari variabel yang diteliti di penelitian ini.

Pada hasil uji hipotesis telah disajikan signifikansi serta besaran pengaruh antara variabel Identifikasi Merek dan Cinta kepada Merek. Hasil uji hipotesis menunjukkan bahwa terdapat 


\section{Jurnal Ekonomi Modernisasi, 13 (2) 2017, 94-104}

pengaruh Identifikasi Merek terhadap Cinta kepada Merek, sehingga disimpulkan hipotesis 1 diterima dengan arah hubungan positif. Berdasarkan hasil analisis data jawaban responden, diketahui bahwa responden yang merupakan anggota komunitas video games merasa bahwa video games The Elder Scrolls merupakan ekstensi dari diri mereka, mereka merasa bahwa ketika merek ini dipuji, mereka juga turut merasa terpuji, mereka tertarik untuk mengetahui apa yang orang lain pikirkan terhadap video games ini, mereka juga merasa bahwa kesuksesan franchise The Elder Scrolls membuat mereka bahagia, karena mereka merasa turut andil bagian dalam kesuksesan ini, dan yang terakhir mereka juga turut tersinggung ketika ada orang lain yang mengkritik secara negatif merek ini.

Hasil penelitian ini sejalan dengan penelitian yang dilakukan oleh Kressmann et al. (2006) dan Bergkvist dan Bech-Larsen (2010), mereka menyatakan bahwa identifikasi merek mempengaruhi rasa cinta kepada merek (Brand Love). Semakin seseorang menganggap bahwa sebuah merek adalah ekstensi dari dirinya, maka ia akan memiliki perasaan emosional yang dalam kepada merek tersebut.

Hasil uji hipotesis juga menunjukkan bahwa terdapat pengaruh Citra Merek terhadap Cinta kepada Merek, sehingga disimpulkan hipotesis 2 diterima. Berdasarkan hasil analisis jawaban responden, yang merupakan anggota komunitas video games The Elder Scrolls, diketahui bahwa responden merasa bahwa francise The Elder Scrolls memiliki keunikan dan karakteristik tersendiri yang dapat membedakan dirinya dengan merek lain yang sejenis, responden juga merasa bahwa mereka memiliki banyak alasan untuk memilih merek ini daripada merek lainnya, mereka pun mempercayai perusahaan induk yang mengembangkan franchise video games ini, selain itu, mereka merasa bahwa video games ini merupakan bagian hidup mereka dan mereka merasa sangat familiar dengan merek ini. Hasil penelitian ini sesuai dengan hasil penelitian Spinelli dan Ismail (2012), mereka lakukan menunjukkan bahwa citra merek memiliki pengaruh terhadap rasa cinta kepada merek (Brand Love). Ketika konsumen mengasosiasikan merek tertentu dengan dirinya, maka komponen afektif dari sikap konsumen terhadap merek tersebut akan tersentuh sehingga timbul rasa cinta kepada merek yang dimaksud.

Pengaruh Identifikasi Merek dan Citra Merek secara simultan terhadap Cinta kepada Merek ditunjukkan melalui uji hipotesis ketiga, sehingga uji hipotesis dapat disimpulkan bahwa hipotesis 3 diterima. Hasil penelitian ini memiliki arti bahwa Identifikasi Merek dan Citra Merek adalah antaseden-antaseden penting dalam membangun rasa Cinta kepada Merek. Love affair antara merek dengan konsumen dapat dibangun dengan menyelaraskan citra merek yang dipersepsikan oleh konsumen dengan citra merek yang dibangun oleh perusahaan (Roberts, 2005). Apabila konsumen menilai bahwa suatu merek dapat merepresentasikan dirinya maka ia akan mencintai merek tersebut.

Berdasarkan pada hasil dan pembahasan yang telah dilakukan atas analisis Identifikasi Merek, Citra Merek, dan Cinta kepada Merek (Brand Love), peneliti menyadari bahwa terdapat 


\section{Ferdian Hendrasto / Peran Identifikasi Merek dan Citra Merek .....}

beberapa keterbatasan yang menghambat penelitian dan berpotensi menjadi kelemahan penelitian ini. Keterbatasan tersebut adalah cakupan penelitian yang terbatas dalam komunitas video games. Selain itu, identifikasi faktor-faktor lain yang tidak termasuk dalam penelitian ini juga perlu dilakukan untuk memperkaya hasil penelitian ini.

\section{Simpulan}

Identifikasi Merek berpengaruh signifikan terhadap Cinta kepada Merek. Hal ini membuktikan bahwa rasa cinta yang tumbuh dalam diri anggota komunitas online video game Elder Scrolls berkembang dengan baik. Anggota komunitas merasa bahwa video game tersebut adalah ekstensi dari diri mereka sendiri, sehingga mereka merasa memiliki ikatan emosional dengan video game tersebut. Citra merek juga berpengaruh signifikan terhadap Cinta kepada Merek. Hal ini membuktikan bahwa ketika anggota komunitas mengasosiasikan secara positif video game tersebut, akan timbul ikatan emosional antara merek tersebut dengan konsumen. Adanya Cinta kepada Merek, maka anggota komunitas ini akan menjadi fanbase yang loyal bagi perusahaan. Pelanggan yang loyal akan memberikan keuntungan bagi perusahaan.

Penelitian ini menunjukkan bahwa Identifikasi Merek dan Citra Merek adalah antaseden penting bagi Cinta kepada Merek. Namun rasa Cinta kepada Merek sendiri juga dapat menjadi antaseden bagi variabel lain, misalnya loyalitas dan WOM (Carroll \& Ahuvia, 2006). Penelitian di masa yang akan datang juga dapat meneliti tidak terbatas dalam satu komunitas saja, namun dari beberapa komunitas sehingga hasil penelitian dapat lebih digeneralisasi.

Bethesda sebagai perusahaan induk yang memiliki merek franchise video games Elder Scrolls telah menerapkan strategi yang baik dalam membangun identifikasi merek dan citra merek yang positif dalam diri pelanggan. Namun terdapat beberapa aspek yang dapat ditingkatkan, misalnya persepsi komunitas video games secara umum yang menganggap bahwa games buatan Bethesda selalu memiliki banyak bugs, ini merupakan asosiasi negatif yang hendaknya dihindari oleh Bethesda. Oleh karena itu, Bethesda dapat meningkatkan pengawasan kualitas video games yang diluncurkan agar tidak terlalu banyak bugs yang terdapat dalam video games buatan mereka.

\section{Daftar Pustaka}

Aaker, D. A. (1996). Building Strong Brands. New York: The Free Press.

Ahuvia, A. C., \& Wong, N. (1995). Materialism: Origins and Implications For Personal WellBeing. European Advances in Consumer Research, 2, 172-178. Retrieved from http:// acrwebsite.org/volumes/11092/ volumes/e02/E-02

Bagozzi, R. P., \& Dholakia, U. M. (2006). Antecedents and Purchase Consequences of Customer Participation in Small Group Brand Communities. International Journal of Research in Marketing, 23(1), 45- 


\section{Jurnal Ekonomi Modernisasi, 13 (2) 2017, 94-104}

61. https://doi.org/10.1016/ j.ijresmar.2006.01.005

Batra, R., Ahuvia, A., \& Bagozzi, R. P. (2012). Brand love. Journal of Marketing, 76(2), 1-16. https:/ doi.org/10.1509/jm.09.0339

Bauer, H. H. H., Albrecht, C. C.-M., \& Heinrich, D. (2009). All You Need Is Love: Assessing Consumers' Brand Love. Proceedings of the American Marketing Association Summer Educators Conference, 15(2), 252-253.

Bergkvist, L., \& Bech-Larsen, T. (2010). Two studies of consequences and actionable antecedents of brand love. Journal of Brand Management, 17(November 2009), 504-518. https://doi.org/10.1057/bm.2010.6

Carroll, B. A., \& Ahuvia, A. C. (2006). Some antecedents and outcomes of brand love. Marketing Letters, 17(2), 79-89. https://doi.org/10.1007/ s11002-006-4219-2

Dobni, D., \& Zinkhan, G. M. (1990). In Search of Brand Image: a Foundation Analysis. Advances in Consumer Research, 17, 110-119. Retrieved from http://acrwebsite.org/ volumes/7005/volumes/v17/NA17

Fournier, S. (1998). Consumers and their brands: Developing relationship theory in consumer research. The Journal of Consumer Research, 24(4), 343-373.

Grunebarum, H. (1997). Thinking About Romantic/Erotic Love. Journal of Marital and Family Therapy, 23(3), 295-307. https://doi.org/10.1111/ j.1752-0606.1997.tb01037.x

Hair, J. F., Black, W. C., Babin, B. J., \& Anderson, R. E. (2010). Multivariate
Data Analysis: A Global Perspective, 7th Edition (7th Editio). New Jersey: Pearson Education.

Keller, K. L. (1993). Conceptualizing, Measuring, and Managing CustomerBased Brand Equity. Journal of Marketing, 57(1), 1-22. https:// doi.org/10.2307/1252054

Keller, K. L., Heckler, S. E., \& Houston, M. J. (1998). The Effects of Brand Name Suggestiveness on Advertising Recall. Journal of Marketing, 62(1), $48-57$. ht t p s : / / doi.org/10.2307/1251802

Koubaa, Y. (2008). Country of origin , brand image perception, and brand image structure Country of origin , brand image perception, and brand image structure. Asia Pacific Journal of Marketing and Logistics, 20(2), $139-155$. h t t p s : / / doi.org/10.1108/1355585081086452 4

Kressmann, F., Sirgy, M. J., Herrmann, A., Huber, F., Huber, S., \& Lee, D. (2006). Direct and indirect effects of self-image congruence on brand loyalty. Journal of Business Research, 59(9), 955-964. https:// d o i.org/ $10.1016 /$ j.jbusres.2006.06.001

Langner, T., Bruns, D., Fischer, A., \& Rossiter, J. R. (2016). Falling in love with brands: a dynamic analysis of the trajectories of brand love. Marketing Letters, 27(1). https:// doi.org/10.1007/s11002-014-9283-4

Rauschnabel, P. A., \& Ahuvia, A. C. (2014). You're So Loveable: Anthropomorphism and Brand Love. Journal of Brand Management, 21 (April), 1-39. https:// doi.org/10.1057/bm.2014.14

Roberts, K. (2005). Lovemarks: the Future Beyond Brands. Brooklyn: power- 
House Books.

Roy, D., \& Banerjee, S. (2008). Caring Strategy for Integration of Brand Identity with Brand Image. International Journal of Commerce and Management, 17(1/2), 140-148. $\mathrm{h} \quad \mathrm{t} \quad \mathrm{t} \quad \mathrm{p} \quad \mathrm{s}$ : / doi.org/10.1108/105692107107765 12

Severi, E., \& Ling, K. C. (2013). The mediating effects of brand association, brand loyalty, brand image and perceived quality on brand equity. Asian Social Science, 9(3), 125-137. https://doi.org/10.5539/ ass.v9n3p125

Shimp, T. A., \& Madden, T. J. (1988). Consumer-Object Relations: a Conceptual Framework Based Analogously on Sternberg's Triangular Theory of Love. Advances in Consumer Research, 15, 163-168. Retrieved from http://acrwebsite.org/ volumes/6810/volumes/v15/NA15

Sirgy, M. J., Grewal, D., Mangleburg, T. F., Park, J.-O., Chon, K.-S., Claiborne, C. B., ... Berkman, H. (1997). Assessing the Predictive Validity of Two
Methods of Measuring Self-Image Congruence. Journal of the Academy of Marketing Science, 25(3), 229-241. $\mathrm{h} \mathrm{t} \mathrm{t} \quad \mathrm{p} \quad \mathrm{s}$ : / / doi.org/10.1177/0092070397253004

So, K. K. F., King, C., Sparks, B., \& Wang, Y. (2013). The influence of customer brand identification on hotel brand evaluation and loyalty development. International Journal of Hospitality Management, 34(1), 31-41. https:// doi.org/10.1016/j.ijhm.2013.02.002

Spinelli, G., \& Ismail, A. R. (2012). Effects of brand love, personality and image on word of mouth. Journal of Fashion Marketing and Management, 11 (4), $\quad 571-586$. https:// doi.org/10.1108/0309056041053930 2

Whang, Y.-O., Allen, J., Sahoury, N., \& Zhang, H. (2004). Falling in Love with a Products: the Structure of a Romantic Consumer-Product Relationship. Advances in Consumer Research, 31, 320-327. Retrieved from http://www.acrwebsite.org/ volumes/8907/volumes/v31/NA31 